\title{
I.UMIBUNG
}

\section{EKSPLORASI DAN KARAKTERISASI HANJELI (Coix lacryma-jobi L) DI KABUPATEN LIMAPULUH KOTA}

\author{
Ayu Kurnia Illahi ${ }^{1}$, Yusniwati ${ }^{2}$, Etti Swasti $^{2}$ \\ ${ }^{1}$ Politeknik Pertanian Negeri Payakumbuh \\ ${ }^{2}$ Universitas Andalas \\ Korespondensi: ayu10yurizal@gmail.com
}

\author{
Diterima : 11 Juni 2020 \\ Disetujui : 27 Februari 2021 \\ Diterbitkan : 28 Februari 2021
}

\begin{abstract}
ABSTRAK
Hanjeli (Coix lacryma -jobi L) adalah tanaman serealia yang dapat dimanfaatkan sebagai pangan dan pakan. Penelitian eksplorasi dan karakterisasi hanjeli bertujuan untuk mendapatkan informasi karakter fenotipik hanjeli di Kabupaten Limapuluh Kota sebagai data awal dan untuk pelestarian plasma nutfah hanjeli. Penelitian dilaksanakan pada bulan Februari sampai bulan April 2016, diawali dengan eksplorasi dan dilanjutkan dengan karakterisasi morfologi hanjeli. Data dari setiap sampel dianalisis secara statistik kemudian dibandingkan dengan sampel lainnya. Data morfologi ditampilkan secara deskriptif. Hasil penelitian menunjukkan pada 74 aksesi yang diperoleh dari delapan kecamatan di Kabupaten Lima Puluh Kota memiliki bentuk batang bulat dengan permukaan licin dan arah tumbuh tegak, daun tanaman hanjeli merupakan daun lengkap, bunga hanjeli merupakan bunga sempurna tidak lengkap karena tidak memiliki bagian calix dan carolla.
\end{abstract}

Kata Kunci: eksplorasi, hanjeli, karakterisasi, morfologi, pemuliaan

\begin{abstract}
Job's tears (Coix lacryma -jobi L) is a cereal crop that can be used as food and feed. Research on exploration and characterization of job's tears aims to obtain information on the phenotypic characters of job's tears in Lima Puluh Kota Regency as initial data and for the preservation of job's tears germplasm. The research was conducted from February to April 2016, beginning with exploration and continued with the morphological characterization of job's tears. Data from each sample were statistically analyzed and then compared with other samples. Morphological data are presented descriptively. The results showed that 74 accessions obtained from eight districts in Lima Puluh Kota Regency have round stem shape with smooth surface and upright growth direction, hanjeli plant leaves are complete leaves, hanjeli flower is a perfect incomplete flower because it does not have calix and carolla parts.
\end{abstract}

Keywords: breeding, exploration, characterization, job's tears, morphology 


\section{I.UMBUNSC}

\section{PENDAHULUAN}

Peningkatan jumlah penduduk akan sejalan dengan peningkatan kebutuhan untuk memenuhi sumber pangan penduduk. Di Indonesia telah banyak dikenal dan dikembangkan tanaman sumber pangan, seperti padi, jagung, sorgum, gandum, dan sagu. Kebutuhan penduduk Indonesia terhadap sumber pangan belum terpenuhi, sehingga perlu pengembangan sumber pangan dari tanaman lain.

Nurmala dan Irwan (2007) menyatakan tanaman hanjeli merupakan bahan pangan alternatif non beras yang mudah dibudidayakan, tahan hama dan penyakit, toleran terhadap kekeringan dan kebanjiran, serta memiliki adaptasi luas pada berbagai kondisi lingkungan.

Tanaman hanjeli memiliki karakteristik seperti rumput tegak, bercabang kuat, tingginya dapat mencapai $3 \mathrm{~m}$. Buluhterisi dengan empulur, bercabang pada bagian atasnya. Daun besar dan berpelepah, helaian daun memita sampai membundar telur-melanset, tepi daun kasar, halus atau kasap permukaan atasnya. Perbungaan di ketiak daun paling atas, soliter atau terdiri dari 2-7 berkas, putih atau kebiruan, mengandung 2 tandan; tandan betina mengandung buliran yang duduk, buliran dengan 1 floret, tandan jantan dengan kira-kira 10 buliran yang menyirap dan muncul berpasangan atau tiga-tiga, 1 mempunyai gantilan lainnya duduk; buliran melanset sampai menjorong, mengandung 1-2 floret jantan. Buah bervariasi dalam ukuran, bentuk, warna dan kekerasannya, biasanya berwarna abu-abu, kuning-merah tua atau keunguan, lunak atau keras, berisi jali. Jali berwarna merah tua untuk yang berkulit keras, atau merah muda untuk yang berkulit lunak (Prohati, 2016). Komposisi nutrisi kimia hanjeli dibandingkan serealia lainnya dapat dilihat pada Tabel 1.

Tabel 1. Komposisi kimia tanaman serealia dalam $100 \mathrm{~g}$ biji serealia

\begin{tabular}{lccccc}
\hline Komposisi kimia & Jagung putih & $\begin{array}{c}\text { Jagung } \\
\text { kuning }\end{array}$ & Sorghum & Jewawut & Hanjeli \\
\hline Kalori (g) & 355 & 355 & 332 & 334 & 289 \\
Protein (g) & 9.2 & 9.2 & 11 & 9.7 & 11 \\
Lemak (g) & 3.9 & 3.9 & 3.3 & 3.5 & 4 \\
Karbohidrat (g) & 73.7 & 73.7 & 73 & 73.4 & 61 \\
Kalsium (mg) & 10 & 10 & 28 & 28 & 213 \\
Fosfor (mg) & 256 & 256 & 287 & 311 & 176 \\
Besi (mg) & 2.4 & 2.4 & 4.4 & 5.3 & 11 \\
\hline
\end{tabular}

Sumber: BPPTEPUS, 2011.

Gabungan antara potensi sebagai olahan pangan yang nikmat dan khasiatnya sebagai obat menjadikan hanjeli sebagai salah satu komoditas pertanian yang potensial (Douangsavanh dan Bouahom, 2006). 


\section{I.UMIRUNG}

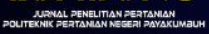

Meningkatkan produktivitas dan kualitas hasil, maka perlu dilakukan inventarisasi, koleksi, karakterisasi dan evaluasi tumbuhan yang sudah ada untuk mencegah adanya erosi genetik yang berakibat pada hilangnya sumber genetik. Eksplorasi merupakan kegiatan mencari, menemukan, dan mengumpulkan sumberdaya genetik (SDG) tertentu untuk mengamankannya dari kepunahan. Plasma nutfah yangditemukan perlu diamati sifat dan asalnya kemudian dilakukan upaya-upaya pelestarian. Eksplorasi plasmanutfah dilakukan secara purposif pada daerah-daerah sentra produksi, daerah produksi tradisional, daerah terisolir, daerah pertanian lereng-lereng gunung, pulau terpencil, daerah sukuasli, daerah dengan sistem pertaniantradisional belum maju, dan daerah yang masyarakatnyamenggunakan komoditas yang bersangkutan sebagai bahanmakanan pokok utama (Suryani dan Nurmansyah, 2009).

\section{METODE PENELITIAN}

Penelitian ini dilakukan pada bulan Februari sampai April 2016 dengan menggunakan metode survei dengan pengambilan sampel secara sengaja (Purpossive Sampling). Pengumpulan data lokasi yang dijadikan tempat untuk pengambilan sampel dilakukan melalui survei pendahuluan. Informasi diperoleh dari masyarakat, dan pencarian langsung di lapangan tempat keberadaan tanaman hanjeli. Berdasarkan hasil survei pendahuluan, kecamatan yang memiliki tanaman hanjeli di Kabupaten Lima Puluh Kota dijadikan sebagai lokasi penelitian. Data dari setiap sampel dianalisis secara statistik kemudian dibandingkan dengan sampel lainnya. Data morfologi ditampilkan secara deskriptif.

Bahan yang dibutuhkan pada penelitian ini adalah aksesi tanaman hanjeli yang terdapat di Kabupaten Lima Puluh Kota. Alat yang dibutuhkan pada penelitian ini adalah jangka sorong, color chart, meteran, kantong plastik, kamera digital, kertas label, pisau, gunting, sabit, GPS (Global Pasitioning System)Map 76 CS x , mistar, tisu, dan alat tulis.

\section{HASIL DAN PEMBAHASAN}

Pada penelitian ini telah diakukan eksplorasi tanaman hanjeli di Kabupaten Limapuluh Kota, sehingga diperoleh informasi mengenai lokasi keberadaan tanaman hanjeli. Dari 13 kecamatan di Kabupaten Limapuluh Kota hanya delapan kecamatan yang dapat ditemui keberadaan tanaman hanjeli. Informasi ini diperoleh dari masyarakat dan pencarian langsung ke lapangan. Penentuan tanaman yang dijadikan sampel pengamatan adalah tanaman yang telah memasuki fase generatif yang ditandai dengan telah munculnya bunga 


\section{I.UMIBUNC}

dan memiliki tinggi tanaman $>50 \mathrm{~cm}$, hal ini dikarenakan tanaman hanjeli memiliki tinggi berkisar antara 1 m-3 m. Kecamatan yang menjadi lokasi penelitian dapat dilihat di Tabel 2 .

Tabel 2. Lokasi Pengambilan sampel tanaman hanjeli di Kabupaten Limapuluh Kota

\begin{tabular}{|c|c|c|c|c|c|c|}
\hline \multicolumn{2}{|r|}{ Lokasi } & \multirow{2}{*}{$\begin{array}{c}\text { Kode } \\
\text { Aksesi }\end{array}$} & \multirow{2}{*}{$\begin{array}{c}\text { Jumlah } \\
\text { aksesi }\end{array}$} & \multirow{2}{*}{$\begin{array}{c}\text { Ketinggian } \\
(\text { mdpl })\end{array}$} & \multirow{2}{*}{$\begin{array}{l}\text { Lintang } \\
\text { Selatan }\end{array}$} & \multirow{2}{*}{ Bujur Timur } \\
\hline Kecamatan & Nagari & & & & & \\
\hline Akabiluru & Piladang & AKB 1 & 1 & 569 mdpl & $00^{\circ} 15^{\prime} 50.5^{\prime \prime}$ & $100^{\circ} 34^{\prime} 36.0^{\prime \prime}$ \\
\hline Akabiluru & Koto Tangah Batu Hampa & $\mathrm{AKB} 2$ & 1 & 619 mdpl & $00^{\circ} 15^{\prime} 33.7^{\prime \prime}$ & $100^{\circ} 33^{\prime} 33.9{ }^{\prime \prime}$ \\
\hline Akabiluru & Koto Tangah Batu Hampa & AKB 3 & 4 & $612 \mathrm{mdpl}$ & $00^{\circ} 15^{\prime} 27.7^{\prime \prime}$ & $100^{\circ} 33^{\prime} 28.8^{\prime \prime}$ \\
\hline Akabiluru & Batu Hampa & AKB 4 & 1 & $589 \mathrm{mdpl}$ & $00^{\circ} 14^{\prime} 58.5^{\prime \prime}$ & $100^{\circ} 33^{\prime} 07.4^{\prime \prime}$ \\
\hline Akabiluru & Batu Hampa & AKB 5 & 2 & 593 mdpl & $00^{\circ} 14^{\prime} 56.4^{\prime \prime}$ & $100^{\circ} 33^{\prime} 04.8^{\prime \prime}$ \\
\hline Akabiluru & SariakLaweh & AKB 6 & 1 & $559 \mathrm{mdpl}$ & $00^{\circ} 13^{\prime} 01.6^{\prime \prime}$ & $100^{\circ} 31^{\prime} 53.6 "$ \\
\hline Harau & Jorong Solok Dalam, Solok Bio-Bio & HRU 1 & 1 & $515 \mathrm{mdpl}$ & $00^{\circ} 07^{\prime} 12.2^{\prime \prime}$ & $100^{\circ} 39^{\prime} 01.4^{\prime \prime}$ \\
\hline Harau & Jorong Solok Dalam, Solok Bio-Bio & HRU 2 & 1 & $517 \mathrm{mdpl}$ & $00^{\circ} 06^{\prime} 47.2^{\prime \prime}$ & $100^{\circ} 38^{\prime} 47.2^{\prime \prime}$ \\
\hline Harau & Jorong Solok Dalam, Solok Bio-Bio & HRU 3 & 1 & $517 \mathrm{mdpl}$ & $00^{\circ} 86^{\prime} 47.3^{\prime \prime}$ & $100^{\circ} 38^{\prime} 47.2^{\prime \prime}$ \\
\hline Harau & Jorong Solok Dalam, Solok Bio-Bio & HRU 4 & 1 & $527 \mathrm{mdpl}$ & $00^{\circ} 06^{\prime} 38.1^{\prime \prime}$ & $100^{\circ} 38^{\prime} 33.6 ”$ \\
\hline Harau & Jorong Solok Dalam, Solok Bio-Bio & HRU 5 & 2 & $527 \mathrm{mdpl}$ & $00^{\circ} 06^{\prime} 37.5^{\prime \prime}$ & $100^{\circ} 38^{\prime} 33.3 "$ \\
\hline Harau & Jorong Solok Dalam, Solok Bio-Bio & HRU 6 & 1 & $520 \mathrm{mdpl}$ & $00^{\circ} 06^{\prime} 38.6^{\prime \prime}$ & $100^{\circ} 38^{\prime} 33.4 "$ \\
\hline Harau & $\begin{array}{l}\text { Jorong Padang Ambacang, Batu } \\
\text { Balang }\end{array}$ & HRU 7 & 1 & $507 \mathrm{mdpl}$ & $00^{\circ} 11 ' 38.6^{\prime \prime}$ & $100^{\circ} 38^{\prime} 33.4^{\prime \prime}$ \\
\hline Harau & Jorong Koto Harau, Batu Balang & HRU 8 & 1 & $503 \mathrm{mdpl}$ & $00^{\circ} 11^{\prime} 10.8^{\prime \prime}$ & $100^{\circ} 40^{\prime} 15.0^{\prime \prime}$ \\
\hline Harau & Jorong Koto Harau, Batu Balang & HRU 9 & 1 & $512 \mathrm{mdpl}$ & $00^{\circ} 11^{\prime} 10.4^{\prime \prime}$ & $100^{\circ} 40^{\prime} 14.6 "$ \\
\hline Harau & Jorong Balai, Batu Balang & $\begin{array}{l}\text { HRU } \\
10\end{array}$ & 1 & $508 \mathrm{mdpl}$ & $00^{\circ} 11^{\prime} 20.6 ”$ & $100^{\circ} 40^{\prime} 39.8^{\prime \prime}$ \\
\hline Kapur IX & Jorong Koto Tinggi, Muaro Paiti & KPR 1 & 3 & $136 \mathrm{mdpl}$ & $00^{\circ} 14^{\prime} 37.7^{\prime \prime}$ & $100^{\circ} 32^{\prime} 40.9{ }^{\prime \prime}$ \\
\hline Luhak & TanjuangKaliang & LHK 1 & 3 & $546 \mathrm{mdpl}$ & $00^{\circ} 14^{\prime} 34.6 "$ & $100^{\circ} 40^{\prime} 39.7^{\prime \prime}$ \\
\hline Luhak & TanjuangKaliang & LHK 2 & 1 & $543 \mathrm{mdpl}$ & $00^{\circ} 14^{\prime} 34.5^{\prime \prime}$ & $100^{\circ} 40^{\prime} 40.4 "$ \\
\hline Luhak & TanjuangKaliang & LHK 3 & 1 & $522 \mathrm{mdpl}$ & $00^{\circ} 14^{\prime} 32.3^{\prime \prime}$ & $100^{\circ} 40^{\prime} 43.3{ }^{\prime \prime}$ \\
\hline Mungka & $\begin{array}{l}\text { Jorong KampuangTangah, Talang } \\
\text { Maua }\end{array}$ & MGK 1 & 1 & $545 \mathrm{mdpl}$ & $00^{\circ} 04^{\prime} 21.9^{\prime \prime}$ & $100^{\circ} 33^{\prime} 47.8^{\prime \prime}$ \\
\hline Mungka & Jorong Talang, Talang Maua & MGK 2 & 4 & $551 \mathrm{mdpl}$ & $00^{\circ} 03^{\prime} 47.5^{\prime \prime}$ & $100^{\circ} 33^{\prime} 29.0^{\prime \prime}$ \\
\hline Mungka & Jorong SimpangTigoTalang Maua & MGK 3 & 12 & $563 \mathrm{mdpl}$ & $00^{\circ} 03^{\prime} 40.2^{\prime \prime}$ & $100^{\circ} 33^{\prime} 15.0^{\prime \prime}$ \\
\hline Pangkalan & Jorong Pasar, Manggilang & PKL 1 & 1 & $138 \mathrm{mdpl}$ & $00^{\circ} 02^{\prime} 44.3^{\prime \prime}$ & $100^{\circ} 45^{\prime} 22.1$ '” \\
\hline Pangkalan & Jorong Pasar, Manggilang & PKL 2 & 6 & 114 mdpl & $00^{\circ} 02^{\prime} 45.0^{\prime \prime}$ & $100^{\circ} 45^{\prime} 21.9{ }^{\prime \prime}$ \\
\hline Pangkalan & $\begin{array}{l}\text { Jorong Banjarana, Pangkalan Koto } \\
\text { Baru }\end{array}$ & PKL 3 & 3 & 116 mdpl & $00^{\circ} 04^{\prime} 32.6^{\prime \prime}$ & $100^{\circ} 41^{\prime} 53.2^{\prime \prime}$ \\
\hline Payakumbuh & $\begin{array}{l}\text { Jorong Batu Nan Limo, Koto Tangah } \\
\text { Simalanggang }\end{array}$ & PYK 1 & 1 & $513 \mathrm{mdpl}$ & $00^{\circ} 10^{\prime} 34.4^{\prime \prime}$ & $100^{\circ} 36^{\prime} 30.3^{\prime \prime}$ \\
\hline Payakumbuh & $\begin{array}{l}\text { Jorong TambunIjuk, Koto Tangah } \\
\text { Simalanggang }\end{array}$ & PYK 2 & 1 & 519 mdpl & $00^{\circ} 04^{\prime} 32.6^{\prime \prime}$ & $100^{\circ} 41^{\prime} 53.2^{\prime \prime}$ \\
\hline Payakumbuh & $\begin{array}{l}\text { Jorong TambunIjuk, Koto Tangah } \\
\text { Simalanggang }\end{array}$ & PYK 3 & 1 & 515 mdpl & $00^{\circ} 10^{\prime} 13.1^{\prime \prime}$ & $100^{\circ} 36^{\prime} 14.7{ }^{\prime \prime}$ \\
\hline Payakumbuh & $\begin{array}{l}\text { Jorong TambunIjuk, Koto Tangah } \\
\text { Simalanggang }\end{array}$ & PYK 4 & 1 & 527 mdpl & $00^{\circ} 10^{\prime} 14.2^{\prime \prime}$ & $100^{\circ} 36^{\prime} 16.0^{\prime \prime}$ \\
\hline Payakumbuh & Koto Tangah Simalanggang & PYK 5 & 2 & $517 \mathrm{mdpl}$ & $00^{\circ} 10^{\prime} 14.0^{\prime \prime}$ & $100^{\circ} 36^{\prime} 16.0^{\prime \prime}$ \\
\hline Payakumbuh & Jorong BalaiRupih, Simalanggang & PYK 6 & 1 & $503 \mathrm{mdpl}$ & $00^{\circ} 10^{\prime} 37.4^{\prime \prime}$ & $100^{\circ} 36^{\prime} 44.2{ }^{\prime \prime}$ \\
\hline Payakumbuh & Jorong BalaiRupih, Simalanggang & PYK 7 & 3 & $524 \mathrm{mdpl}$ & $00^{\circ} 10^{\prime} 59.5^{\prime \prime}$ & $100^{\circ} 37 ’ 21.3 ”$ \\
\hline Payakumbuh & $\begin{array}{l}\text { Jorong Solok, Koto Tangah } \\
\text { Simalanggang }\end{array}$ & PYK 8 & 1 & $515 \mathrm{mdpl}$ & $00^{\circ} 10^{\prime} 31.1^{\prime \prime}$ & $100^{\circ} 36^{\prime} 25.2^{\prime \prime}$ \\
\hline Payakumbuh & $\begin{array}{l}\text { Jorong Solok, Koto Tangah } \\
\text { Simalanggang }\end{array}$ & PYK 9 & 1 & $522 \mathrm{mdpl}$ & $00^{\circ} 10^{\prime} 31.1 "$ & $100^{\circ} 36^{\prime} 24.4^{\prime \prime}$ \\
\hline Situjuh & $\begin{array}{l}\text { Jorong Sungai Darek, Situjuah } \\
\text { Padang Bacang }\end{array}$ & STJ 1 & 4 & 559 mdpl & $00^{\circ} 16^{\prime} 56.6^{\prime \prime}$ & $100^{\circ} 36^{\prime} 26.6^{\prime \prime}$ \\
\hline Situjuh & Jorong Bumbuang, Situjuah & STJ 2 & 1 & $612 \mathrm{mdpl}$ & $00^{\circ} 17^{\prime} 21.7^{\prime \prime}$ & $100^{\circ} 35^{\prime} 28.11^{\prime \prime}$ \\
\hline Situjuh & Jorong Bumbuang, Situjuah & STJ 3 & 1 & $605 \mathrm{mdpl}$ & $00^{\circ} 17^{\prime} 12.0^{\prime \prime}$ & $100^{\circ} 35^{\prime} 32.6 "$ \\
\hline
\end{tabular}




\section{I.UMIBUNG}

Hasil eksplorasi tanaman hanjeli di beberapa lokasi, diketahui bahwa hanjeli dapat tumbuh pada berbagai kondisi lahan di antaranya lahan tanah kering, di sekitar aliransungai, di tepipematang sawah, dan di dalam kolam yang berisi air. Dari informasi yang diperoleh mengenai tempat hidup hanjeli dapat dikategorikan bahwa tanaman hanjeli memiliki kemampuan hidup pada berbagai kondisi lahan. Tanaman hanjeli di berbagai lokasi tumbuh disajikan pada Gambar 1.

Pendey dan Roy (2011), menyampaikan manfaat tanaman hanjeli ialah daya tahan tanaman, sangat sedikit diserang penyakit dan hama serta membutuhkan sedikit perawatan. Tanaman ini juga bertumbuh di daerah genangan air, tanah asam dan laterit dan tanah terdegradasi, tanah miring.

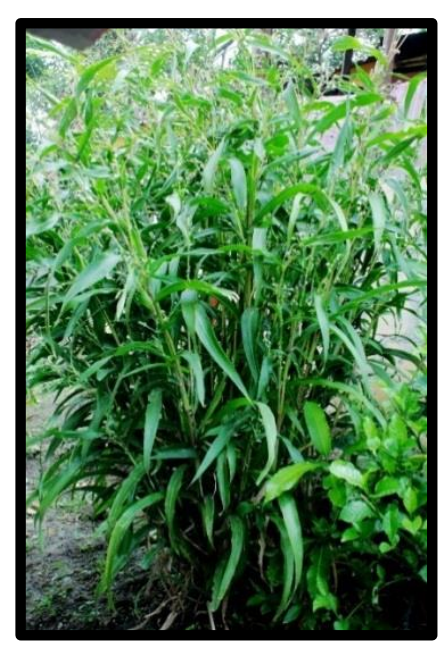

(1)

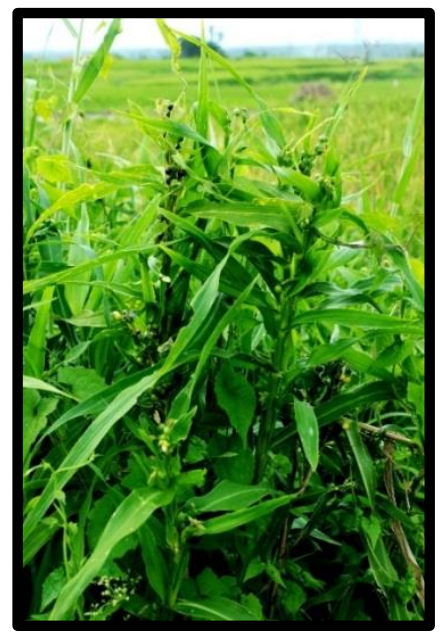

(3)

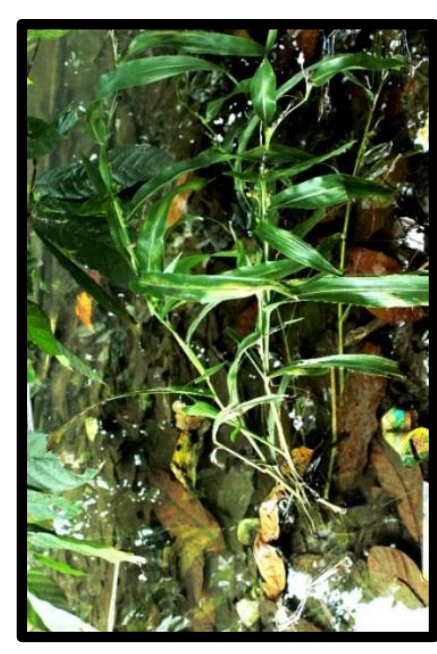

(2)

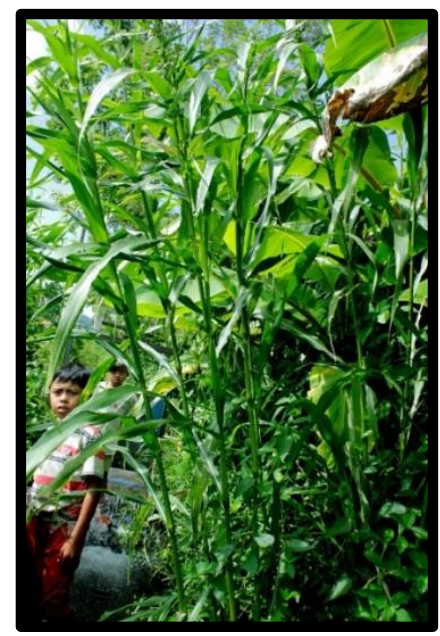

(4)

Gambar 1. Representatif tanaman hanjeli di berbagai habitatnya, 1=lahan tanah; 2=kolam; $3=$ pematang sawah; 4=tepi sungai. 


\section{I.UMIBUNG}

Lokasi pengamatan di Kabupaten Limapuluh Kota tidak ditemukan tanaman hanjeli yang dibudidayakan masyarakat.Hal ini dikarenakan masyarakat yang tidak mengetahui informasi mengenai kandungan dan kegunaan tanaman hanjeli ini. Kegunaan hanjeli yang diketahui oleh masyarakat adalah dalam bidang estetika sebagai hiasan dan bahan untuk membuat kerajinan serta sebagai bahan pakan ternak bagi tanaman hanjeli yang berumur muda. Informasi baru yang diperoleh pada lokasi pengamatan di Kecamatan Situjuh yang menyatakan akar dari tanaman hanjeli yang direbus dan airnya digunakan untuk cairan oles bagian tubuh yang terserang asam urat.

Tanaman hanjeli pada dasarnya sudah pernah dijadikan sebagai bahan pangan masyarakat terutama di Kecamatan Pangkalan, hanya saja dengan perkembangan waktu tanaman hanjeli tidak lagi dikonsumsi oleh masyarakat. Karakter morfologi tanaman hanjeli dilakukan pengamatan dan pengukuran secara langsung pada bagian batang, daun, bunga dan buah terhadap 74 aksesi. Hasil pengamatan dan pengukuran karakter morfologi 74 aksesi hanjeli disajikan pada Tabel 3.

Tabel 3. Nilai kisaran dan rata-rata hasil identifikasi karakter morfologi 74 aksesi tanaman hanjeli di Kabupaten Limapuluh Kota

\begin{tabular}{clll}
\hline No & \multicolumn{1}{c}{ Karakter } & \multicolumn{1}{c}{ Kisaran } & \multicolumn{1}{c}{ Rata-rata } \\
\hline 1. & Bentuk batang & Bulat & Bulat \\
2. & Lingkar batang $(\mathrm{mm})$ & $3.23-14.78$ & 7.65 \\
3. & Permukaan batang & Licin & Licin \\
4. & Warna kulit batang & Hijau tua-hijau kekuningan & Hijau muda \\
5. & Arah tumbuh btang & Tegak & Tegak \\
6. & Warna ruas batang & Hijau tua-hijau kekuningan & Hijau muda \\
7. & Warna nodus & Hijau tua-hijau muda & Hijau tua \\
8. & Tinggi tanaman $(\mathrm{cm})$ & 70.67-239.00 & 141.35 \\
9. & Tipe daun & Lengkap & Lengkap \\
10. & Bangun daun & Pita & Pita \\
11. & Bentuk ujung daun & Meruncing & Meruncing \\
12. & Pertulangan daun & Sejajar & Sejajar \\
13. & Tepi daun & Rata & Rata \\
14. & Tekstur permukan & Berbulu halus dan rapat & Berbulu halus dan \\
15. & Panjang helaian $(\mathrm{cm})$ & rapat \\
16. & Warna helai daun & 26.20-85.93 & H4.03 \\
17. & Lebar helai daun $(\mathrm{cm})$ & Hijau tua-hijau muda & Hijau tua \\
18. & Bentuk pangkal & Rompang & 3.50 \\
19. & Jarak antar helaian $(\mathrm{cm})$ & $8.30-33.10$ & Rompang \\
20. & Warna pucuk muda & Hijau tua-hijau muda & 19.30 \\
21. & Susunan daun & Berseling (alternate) & Hijau tua \\
22. & Warna permukaan atas & Hijau tua-hijau muda & Berseling \\
23. & Warna permukaan bawah & Hijau tua-hijau muda & Hijau tua \\
24. & Keadaan permukaan atas & Tidak mengkilap & Hijau tua \\
25. & Keadaan permukaan bawah & Tidak mengkilap & Tidak mengkilap \\
& & & Tidak mengkilap \\
\end{tabular}




\section{I.UMIBUNG}

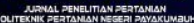

26. Warna tulang daun

27. Panjang pelepah

28. Jumlah anakan

29. Jumlah anakan produktif
Hijau tua-hijau kekuningan

3.67-18.40

4-68

2-65
Hijau muda

7.77

22.21

14.28

\section{Morfologi Batang}

Pengamatan morfologi batang dilakukan pada karakter kualitatif dan karakter kuantitatif. Karakter pengamatan yang termasuk karakter kualitatif adalah bentuk batang, permukaan batang, warna kulit batang, arah tumbuh batang, warna ruas batang, dan warna nodus. Karakter pengamatan tinggi tanaman dan lingkar batang merupakan karakter kuantitatif.

Pada karakter bentuk batang, permukaan batang, dan arah tumbuh batang memiliki hasil pengamatan yang sama untuk setiap aksesi. Pada pengamatan bentuk batang semua aksesi memiliki batang yang berbentuk bulat tanpa rongga di bagian tengah batang. Batang pada setiap aksesi memiliki permukaan batang yang licin, hal ini sama pada kodisi permukaan batang pada tanaman jagung dan memiliki arah tumbuh yang tegak dan lurus ke atas. Dari tiga karakter tersebut dapat disimpulkan bahwa karakter ini memberikan penampilan yang sama dalam kondisi lingkungan yang berbeda seperti pada aksesi pada penelitian ini.

Karakter kualitatif menunjukkan hasil yang berbeda ditemukan pada pengamatan warna kulit batang, warna ruas batang dan warna nodus. Pada pengamatan warna kulit batang dan warna ruas batang menunjukkan hasil yang berkisar hijau tua, hijau muda, dan hijau kekuningan. Aksesi yang memiliki warna kulit dan ruas batang hijau tua sebanyak $18.92 \%$, hijau muda $71.62 \%$, dan $9.46 \%$ hijau kekuningan. Perbedaan warna kulit dan ruas batang pada setiap aksesi dapat dilihat pada Gambar 2.

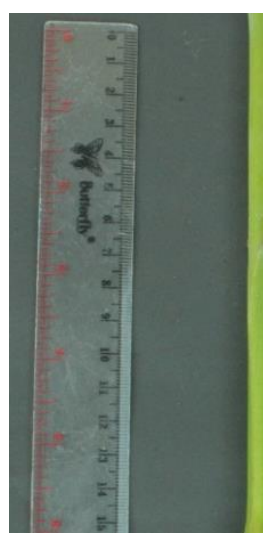

(1)

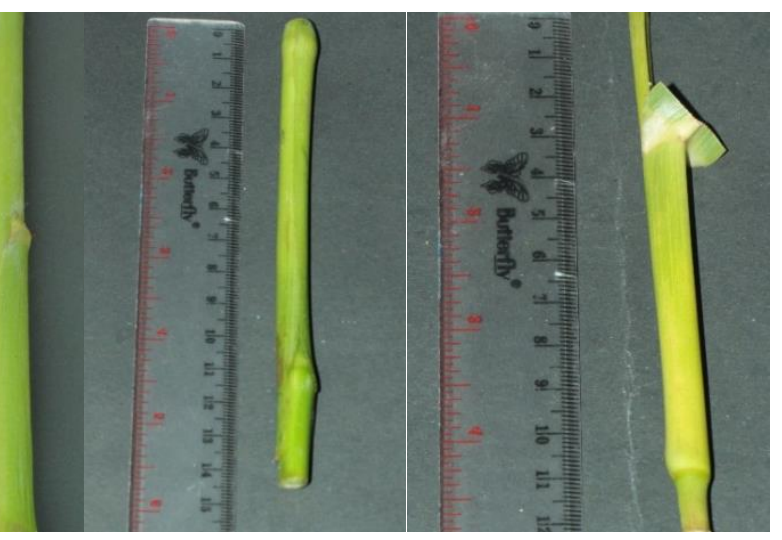

(2)
(3)

Gambar 2. Warna permukaan batang dan ruas pada batang tanaman hanjeli, $1=$ warna hijau tua; 2= warna hijau muda; 3= warna hijau kekuningan 


\section{I.UMBUNSC}

Tanaman hanjeli berbentuk rumpun dengan anakan di sekeliling batang utama. Dari semua aksesi dilakukan pengamatan terhadap jumlah anakan total dan jumlah anakan produktif. Jumlah anakan total diketahui dengan menghitung seluruh jumlah batang hanjeli dalam satu rumpun, sedangkan jumlah anakan produktif dihitung batang yang telah memasuki fase generatif ditandai dengan sudah munculnya organ reproduksi yaitu bunga dan telah terbentuk buah. Dari hasil perhitungan diketahui dalam satu rumpun memiliki jumlah anakan berkisar antara 4-68 batang dengan rata-rata 22 batang, sedangkan jumlah anakan produktif berkisar antara 2-65 batang dengan rata-rata 14 batang dalam satu rumpun. Hidayat (2013) menyampaikan hanjeli merupakan rumpun setahun, rumpunnya banyak, batangnya tegak dan besar, tinggi 1-3 m.

\section{Morfologi Daun}

Pengamatan dilakukan pada karakter kualitatif dan karakter kuantitatif pada bagian daun hanjeli. Karakter yang diamati secara langsung terdiri dari tipe daun, bangun daun, bentuk ujung daun, pertulangan daun, tepi daun, tekstur permukaan, warna helaian, bentuk pangkal, warna pucuk muda, susunan daun, warna permukaan atas, warna permukaan bawah, keadaan permukaan atas, keadaan permukaan bawah, dan warna tulang daun. Sedangkan karakter yang diperlukan pengukuran pada pengamatan morfologi daun ini adalah panjang helaian, lebar helaian, jarak antar helaian, dan panjang pelepah daun. Letak daunnya berseling, helaian daun berbentuk pita, ukuran daun 8-100 x 1,5 cm, ujung daun runcing, pangkalnya memeluk batang, tepinya rata, permukaan kasar, ibu tulang daun menonjol di punggung daun, berbentuk bulir , bunga keluar dari ketiak dan ujung percabangan (Hidayat, 2013).

Hasil pengamatan karakter kualitatif bagian daun hanjeli menunjukkan penampilan yang sama pada karakter tipe daun, bangun daun, bentuk ujung daun, pertulangan daun, tepi daun, tekstur permukaan, bentuk pangkal, susunan daun, keadaan permukaan atas dan keadaan permukaan bawah. Sedangkan pada pengamatan warna helaian, warna pucuk muda, warna permukaan atas, warna permukaan bawah, dan warna tulang daun meliki kisaran tertentu. Daun hanjeli merupakan daun tidak lengkap, karena hanya memiliki helaian dan pelepah. Bentuk daun hanjeli dapat dilihat pada Gambar 3 dan Gambar 4. Hanjeli memiliki bangun daun berbentuk pita dengan bentuk ujung daun yang meruncing dan pangkal daun yang berbentuk rompang. Pertulangan daun hanjeli memiliki tulang daun yang sejajar, tepi daun rata, susunan daun yang berseling, tekstur permukaan yang memiliki bulu halus dan rata dengan keadaan permukaan atas dan bawah daun tidak mengkilap. 


\section{I.UMIBUNG}

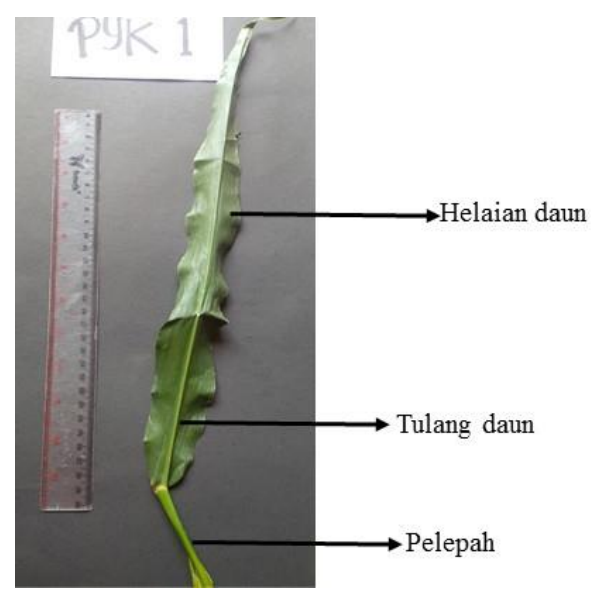

Gambar 3. Bentuk daun hanjeli yang memiliki tipe daun tidak lengkap

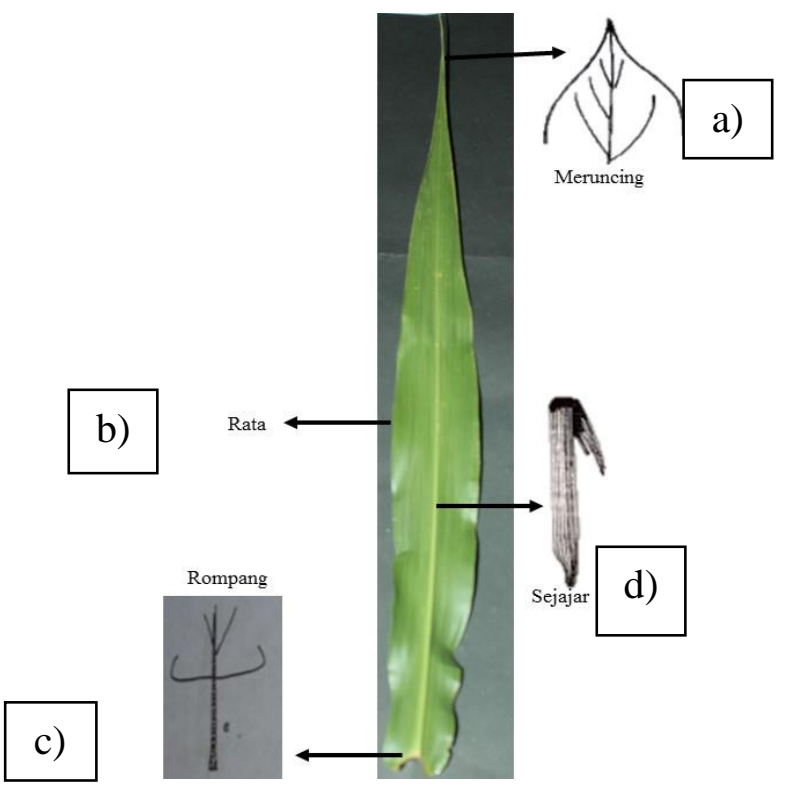

Gambar 4. Bentuk karakter kualitatif pada morfologi daun hanjeli, a)=ujung daun, b)= tepi daun, $\mathrm{c}$ )=pangkal daun, $\mathrm{d}$ )=tulang daun

\section{Morfologi Bunga dan Buah}

Tanaman hanjeli memiliki bunga dan buah majemuk setiap batang di dalam satu rumpun. Tata letak bunga dan buah berada di ujung batang dan di ketiak daun, dengan fase pematangan buah yang tidak merata. Bunga dan buah tanaman hanjeli muncul secara bersamaan, sehingga perkembangan bunga dan buah yang sama. Bunga hanjeli merupakan bunga yang tidak lengkap tetapi merupakan bunga sempurna, hal ini dapat diketahui dari bagian penyusunnya. Bunga hanjeli tidak memiliki bagian calix dan corolla tetapi mempunyai bagian reproduktif jantan dan betina. Fase-fase pembungaan dan perkembangan buah tanaman hanjeli dapat dilihat pada Gambar 5. 


\section{I.UMBUNNC

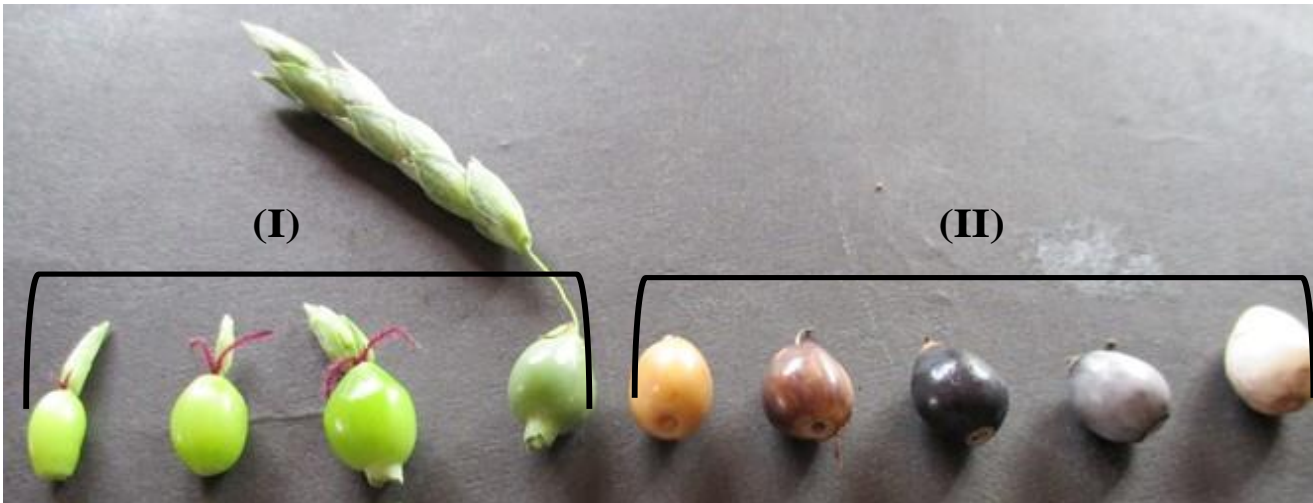

Gambar 5. (I): Fase perkembangan bunga hanjeli, (II): Fase perkembangan bakal buah sampai terbentuknya buah matang

Hasil pengamatan mengenai fase perkembangan bunga dan buah hanjeli dapat diamati mulai dari munculnya bunga juga diikuti dengan munculnya bakal buah yang berada di bawah bagian bunga. Perkembangan buah ini sebelum dan setelah pembuahan ditandai dengan terjadinya perubahan warna dan ukuran pada bagian buahnya. Satu tangkai bunga terdapat bagian-bagian reproduktif pada tanaman, pembungaanhanjeli adalah monoecious dengan bunga jantan dan bunga betina yang terdapat pada spatheoleyang sama. Bagianbagian bunga hanjeli dapat dilihat pada Gambar 6 .

Hasil pengamatan spikelet dari setiap bunga yang diamati, jumlah spikelet yang paling banyak pada satu tangkai berkisar antara 15-26 spikelet. Pada fase antesisantera yang terdapat di dalam spikelet akan memiliki warna kuning sampai kuning kecoklatan. Dengan perkembangan spikelet sampai jumlah maksimum bagian stigma pada bakal buah akan mengering dan berubah warna dari bewarna putih atau merah menjadi bewarna coklat dan kering.

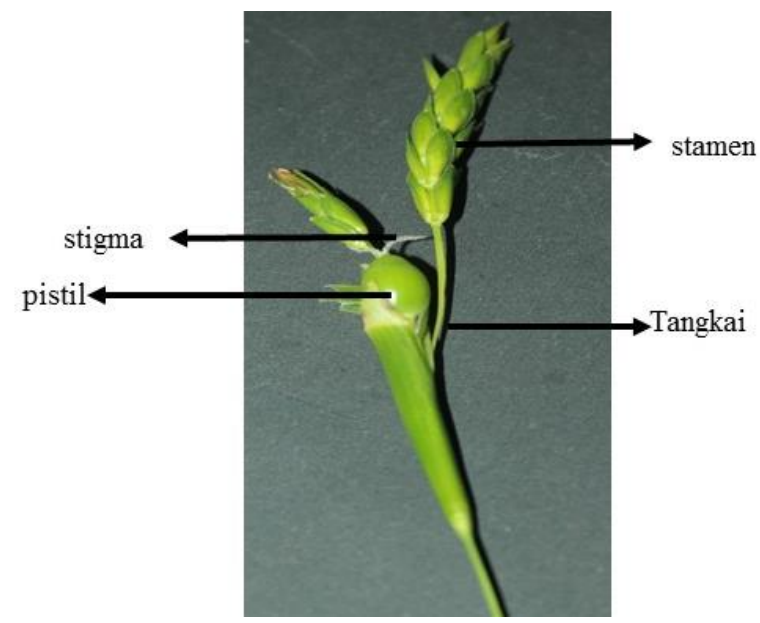

(A)

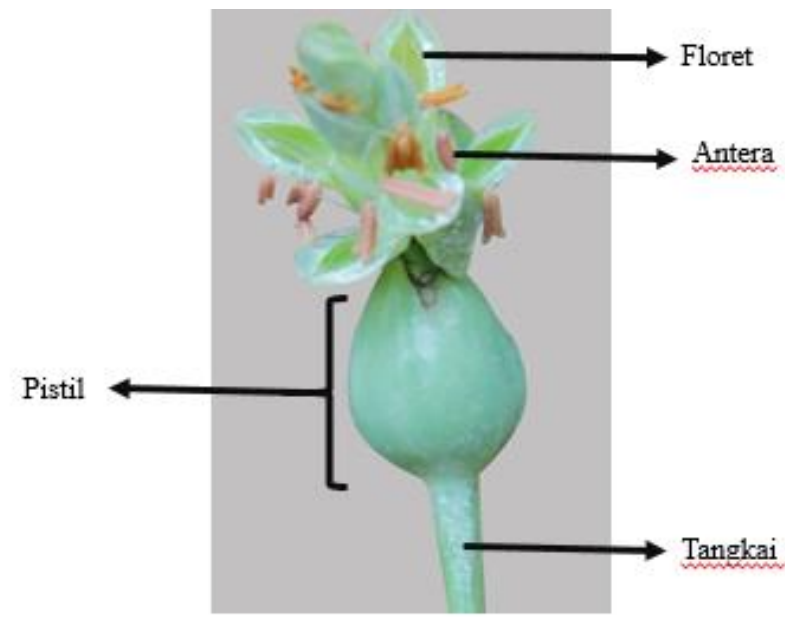

(B)

Gambar 6. Bagian penyusun bunga hanjeli, (A): organ reproduktif tanaman hanjeli, (B): warna antera yang sudah antesis 


\section{I.UMIBUNG}

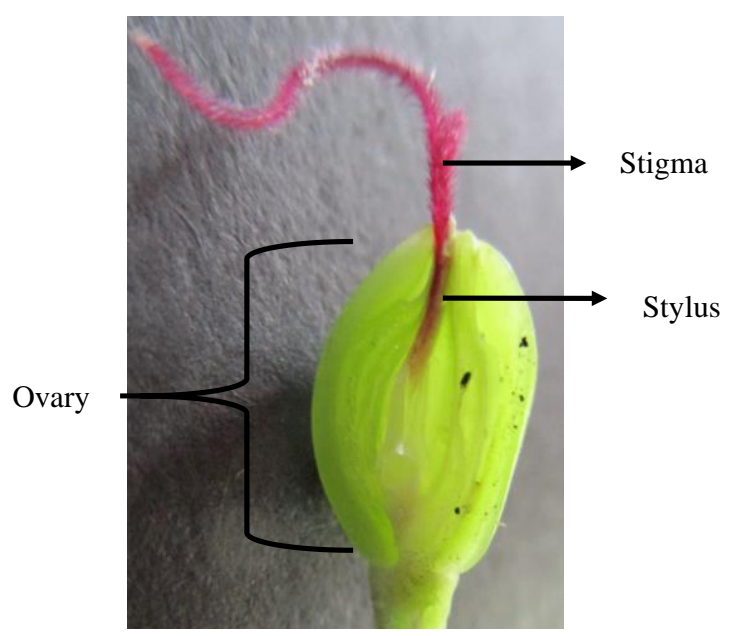

Gambar 7. Bagian bunga betina pada tanaman hanjeli

Hanjeli memperbanyak diri dengan menggunakan biji, dari hasil pengamatan dapat diketahui hanjeli memiliki tipe perkecambahan hipogeal. Dari Burnette, Rick (2012) menyampaikan biji hanjeli membutuhkan waktu 2 minggu untuk berkecambah. Tipe perkecambahan hanjeli dapat dilihat pada Gambar 8.

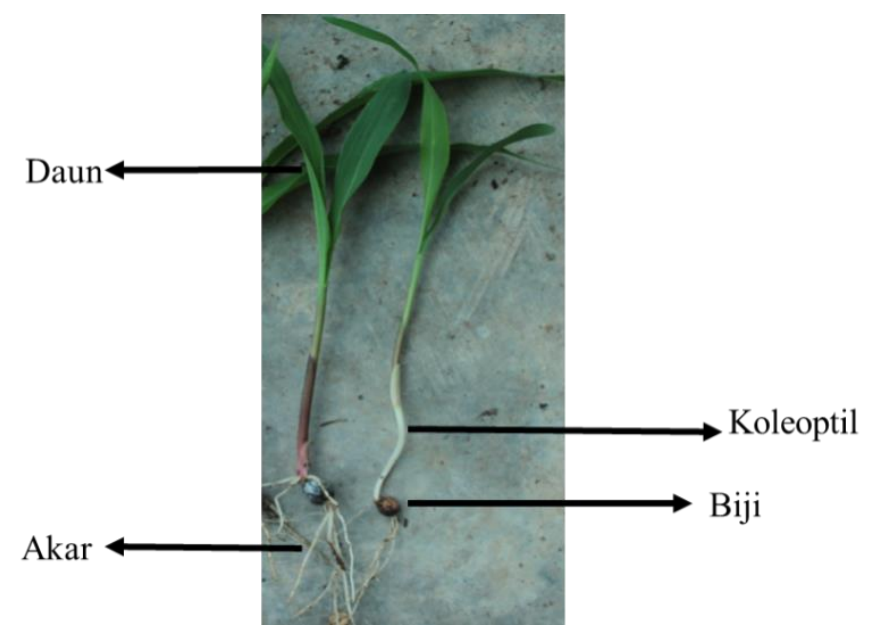

Gambar 8. Tipe perkecambahan hipogeal pada tanaman hanjeli

\section{KESIMPULAN}

Berdasarkan hasil penelitian yang telah dilakukan dapat diambil kesimpulan bahwa eksplorasi tanaman hanjeli di Kabupaten Limapuluh Kota di temukan pada delapan kecamatan sebanyak 74 aksesi. Tempat tumbuh tanaman hanjeli yang ditemukan berkisar pada ketinggian 114-619 m dpl. Hasil eksplorasi tanaman hanjeli dapat tumbuh pada berbagai kondisi lahan di antaranya lahan tanah kering, di sekitar aliran sungai di tepi pematang 


\section{I.UMBUUNG}

sawah, dan di dalam kolam yang berisi air. Morfologi yang diamati adalah karakter kuantitaif dan karakter kualitatif untuk bagian batang, daun, bunga dan buah.

Betuk batang pada setiap aksesi adalah bulat dengan permukaan licin dan arah tumbuh tegak. Daun tanaman hanjeli merupakan daun lengkap, tidak ditemukan banyak variasi pada pengamatan karakter kualitatif berbeda dengan karakter kuantitatif pada morfologi daun. Hanjeli memiliki bunga dan buah majemuk setiap batang dalam satu rumpun, bunga hanjeli merupakan bunga sempurna dan bunga tidak lengkap, karena tidak memiliki bagian calix dan carolla.

\section{REFERENSI}

BPP TEPUS. 2011. Jali Tanaman Palawija Bergizi Dan Berkhasiat. Dikutip dari http://bpptepus.gunungkidulkab.go.id/berita-120-jali-tanaman-palawijabergizi-danberkhasiat.html. Tanggal 30 Maret 2016

Burnette, Rick. 2012. Tiga Kelebihan Jali: Padian Asli Asia Satu Lagi. ECHO Asia Notes. Sebuah Lampiran Regional untuk ECHO Development Notes

Douangsavanh, L., \& B. Bouahom, 2006, Pathways out of Poverty through Maize and Job's Tear in Lao People's Democratic Republic, CAPSA Working Paper No.92, United Nations - Economic and Social Commission for Asia and The Pacific (UN-ESCAP)

Fauza, H. 2005. Identifikasi Karakteristik Gambir (Uncaria spp.) di Sumatera Barat dan Analisis RAPD, Disertasi Fakultas Pertanian Universitas Padjadjaran, Bandung.

Hidayat, M. S. 2013. Pastikan Pasokan Pangan Indonesia, http://www.jurnas.com. Tanggal 23 Maret 2016

Lestari, J. 2014. Kajian tentang Kadar Katekin Tanaman Gambir (Uncaria gambir Roxb.) Ditinjau dar Aspek Ketinggian Tempat dan Genetik, Skripsi Fakultas Pertanian Universitas Andalas, Padang.

Nurmala, T dan A.W. Irwan. 2007. Pangan Alternatif Berbasis Serealia Minor, Giratuna, Bandung

Nurmala, T. 2003. Prospek Jewawut (Pinnisetum spp.) sebagai Pangan Serealia Alternatif. Jurnal Bionatura Vol. 5 No. 1, p. 11-20

Pandey K.C. and A.K. Roy. 2011. Forage Crops Varieties. Indian Grassland dan Fodder Research Institute, Jhansi. http://www.scribd.com/doc/54421060/Forage-CropVarieties. Pawkham, Jamlong. Conversation

Prabowo, S. 2006. Pengolahan dan Pengaruhnya Terhadap Sifat Fisik dan Kimia serta Kualitas Beras (Processing and Its Effect on Physical, Chemical properties and Quality of Rice), Jurnal Teknologi Pertanian Universitas Mulawarman Kampus Gunung Kelua, Samarinda 


\section{I.UMIBUNG}

Suryani E dan Nurmansyah. 2009. Inventarisasi dan Karakterisasi Tanaman Kayu Manis Seilon (Cinnamomum zeylanicum Blume) di Kebun Percobaan-Laing Solok, Bul. Littro 20(2): 99- 105

Swasti, E. 2007. Pengantar Pemuliaan Tanaman, Fakultas Pertanian Universitas Andalas, Padang 